Canadian University Music Review

Canadian University Music Review

Revue de musique des universités canadiennes

\title{
Dancing with the Divine(r): Batá Drumming, Ifá Divination, and Orisha Worship in Cuba
}

\section{Michael Marcuzzi}

Volume 19, numéro 2, 1999

Canadian Perspectives in Ethnomusicology

Perspectives canadiennes en ethnomusicologie

URI : https://id.erudit.org/iderudit/1014448ar

DOI : https://doi.org/10.7202/1014448ar

Aller au sommaire du numéro

Éditeur(s)

Canadian University Music Society / Société de musique des universités canadiennes

ISSN

0710-0353 (imprimé)

2291-2436 (numérique)

Découvrir la revue

Citer cet article

Marcuzzi, M. (1999). Dancing with the Divine(r): Batá Drumming, Ifá Divination, and Orisha Worship in Cuba. Canadian University Music Review / Revue de musique des universités canadiennes, 19(2), 70-78.

https://doi.org/10.7202/1014448ar

\section{Résumé de l'article}

This paper is an examination of similarities between batá drumming and Ifá divination among the Afrocuban socio-religious group, Lukumí. Primarily addressing the use of diametrically opposed social actions within each of these practices, the paper maintains that this juxtaposition of opposites is a constituent characteristic of divining modes-be they interpretive or mediumistic-in effecting suprahuman communication. The paper purports the necessity to examine batá drumming as a divination system; thus, it argues the need for an expanded construct of divination that can readily include musical behaviours such as possession induction.
All Rights Reserved (C Canadian University Music Society / Société de musique des universités canadiennes, 1999
Ce document est protégé par la loi sur le droit d'auteur. L'utilisation des services d'Érudit (y compris la reproduction) est assujettie à sa politique d'utilisation que vous pouvez consulter en ligne.

https://apropos.erudit.org/fr/usagers/politique-dutilisation/ 


\title{
DANCING WITH THE DIVINE(R): BATÁ DRUMMING, IFÁ DIVINATION, AND ORISHA WORSHIP IN CUBA
}

\author{
Michael Marcuzzi
}

This paper is an examination of similarities between batá drumming and Ifá divination among the Afrocuban ${ }^{1}$ socio-religious group, Lukumí. Primarily addressing the use of diametrically opposed social actions within each of these practices, the paper maintains that this juxtaposition of opposites is a constituent characteristic of divining modes-be they interpretive or mediumisticin effecting suprahuman communication. The paper purports the necessity to examine batá drumming as a divination system; thus, it argues the need for an expanded construct of divination that can readily include musical behaviours such as possession induction.

The religious tradition of the Cuban Lukumí is a neo-African descendant of the Ifá religion practised in and around the southwestern quarter of Nigeria and southeastern part of the Republic of Benin. The socio-linguistic group inhabiting this part of sub-Saharan Africa is most often designated today as the Yorùbá people. ${ }^{2}$ The traditional religious practices among the Lukumí ${ }^{3}$ are remarkably similar to those in Nigeria. Due to the exodus of many Cubans from their island during various periods in this century, the Lukumí religion has spread throughout the United States and the Spanish Caribbean, and there are now strong enclaves in Canada, Germany, Spain, and Italy. In addition to what can truly be called an expanding Cuban diaspora, it should be said that there were already various neo-African articulations of this Yorùbá religion throughout the Americas due to the earlier dispersion of Yorùbá slaves; however, it seems that the Cuban articulations of the Ifá religion have been the most

1 I use the term "Afrocuban" when referring to (1) a heritage that is identified with real or imagined practices in Africa, and/or (2) persons whose heredity can be and is willingly traced to Africa. The reason for the single word designation-as opposed to the hyphenated construction "African-Cuban"is simply that it is the designation used by Cubans and Afrocubans. The term seems to have been coined by Fernando Ortiz, a Cuban ethnologist and influential scholar in the Cuban Negritude movement beginning around 1930. These efforts to validate Afrocuban cultural expressions-which preceded the Triumph of the Revolution in 1959-continued to greatly influence many of the social changes brought about by the Cuban Revolution with respect to equality and race relations.

2For a detailed explication of the complexity of this designation, see Christopher Waterman, "“Our Tradition is a Very Modern Tradition': Popular Music and the Construction of Pan-Yorùbá Identity," Ethnomusicology 34, no. 3 (1990): 367-79.

3 Outside of a specifically framed historical context, the designation Lukumí is used in this text as a designation of African heritage and not African heredity. Included among Lukumí devotees are persons of apparently singular European heredity. 
influential in the creation of so many congregations worldwide. ${ }^{4}$ The Yorùbá, therefore, continue to influence the world even through those they, themselves, have influenced. As David Welch says of the Yorùbá, "No African people has had a greater influence in ... the cultures of South America and the Caribbean." 5 Ademola Adegbite writes:

Many casual observers of Yorùbá ways of life ... describe [the] Yorùbá religion as polytheistic ... not realizing that the Yorùbá recognize one God, Olódùmare, as supreme. Similar over-simplifications account for the erroneous description of Yorùbá religion as "fetishism."6

In the Ifá-based religions-whether in Nigeria, Europe, or the Americas-Olódùmarè is regarded as the "contingentless" entity, ${ }^{7}$ disentangled from the world that $\mathrm{He}$ has created. Olódùmarè has no need for affirming his omnipotence through proximity to the devotee and as a result, the Yorùbá have no means of direct supplication. There is no communion with God. Recognizing, however, that human beings are far from contingentless, Olódùmarè dispersed His divine grace (ashé) throughout the universe in the form of the orisha, the spiritual forces that animate an intercessory plane of existence between humankind and Olódùmarè. Each of His orisha govern certain domains of the phenomenal world-the rain, the thunder, fresh water, drumming, a well-crafted tool. The orisha are decidedly human in character. They can dance, flirt, drink too much, forget their keys or hide yours.

The batá drums represent the most sacred and spiritually potent of the sacred drumming traditions practised by orisha devotees in Cuba and the Cuban diaspora. ${ }^{8}$ The batá are considered to be the vessels of Añá, ${ }^{9}$ the spiritual protector of the drums and drummers, who acts as an intercessor between the divine forces and the devotees. The most conspicuous feature of the musical rituals in which batá drumming takes place is possession induction-accessing supranatural forces through the musical-linguistic link of the drum lexicon and

4This is in no way meant to disregard other articulations of the Ifá-based religion such as is the case, for example, of African-Americans who might look solely to Nigeria for the traditional practices of the religion, avoiding the influence and presence-whether real or perceived-of Europeans in these religious practices in the Americas. My statement is simply based on a statistical observation.

5 David Welch, "Aspects of Vocal Performance in Shango Praise-Poetry and Song" (Ph.D. diss., Northwestern University, 1972), 1.

6Ademola Adegbite, "Oríkì: A Study in Yorùbá Musical and Social Perception" (Ph.D. diss., University of Pittsburgh, 1978), 36.

7I am indebted to Prof. Guérin Montilus, Department of Anthropology, Wayne State University, for this idea of "contingentlessness." This idea was put forth in his lecture entitled "Vodu: Environment and the Shaping of a Mythology" (York University, "The Caribbean Religions Project," C.E.R.L.A.C. and Founders College, February 1996). His explication of the Deus perception among West African religions and their Caribbean descendants suggests that the existence and ascendancy of God Supreme is more ample in the West African religions insofar as the positioning of the necessary intercessory agents in the West African religious cosmologies (i.e., orisha/vodun/ancestors) more wholly illustrates the inaccessibility of God.

8 The other three ensembles used in Cuba are the iyesá, the bembé, and the güiro (agbe) ensembles.

9From the Yorùbá, Àyàn. 
procuring the possession of a devotee by an orisha as its praises are being intoned.

Central to the Yorùbá religious paradigm-one shared by the Lukumí community of Cuba-is an intricate tradition of geomancy, a form of divining using the chance-casting of accoutrements. This system, known as Ifá, not only forms a part of present-day Yorùbá-based religious expressions in Cuba but, in various forms, can be found throughout West Africa and Brazil. ${ }^{10} \mathrm{Just}$ as the bata drums are the most important of the drumming styles in Cuba, Ifá is considered the most profound of all the Yorùbá divination systems both in Cuba and abroad. ${ }^{11}$ One of the attributes of this system is the extensive corpus of divination orature ${ }^{12}$ which forms the most comprehensive articulation of the Yorùbá epistemology. ${ }^{13}$ It is through an interpretive mode of applying the divination orature that the actions and desires of the supranatural forces can be rendered intelligible to the client seeking counsel from Ifá. ${ }^{14}$

Anthropological writing on the subject of divination has all too often had a singular focus on the manipulation of accoutrements in geomantic traditions, 15 often becoming "lost in an almost exclusively functionalist mode, which assumed the practice [of divination] to be at best simply supportive of other social systems and at worst irrational and detrimental to its adherents." 16 The negotiating nature of divination, the amalgam of divine potencies vying for control, and the delicate spiritual balance of the client are all very real concerns in these "dynamic systems of knowledge upon which the proper ordering of social action is based." 17 The notion of divining as simply an administered social action is a myth. For orisha worshippers, the divining mat becomes the social space whereby truth is authorized, an effective course of action is determined, and the primary epistemology of the community of believers is articulated. The same can be said of their music making.

10Though there are other forms of divination used by orisha devotees, Ifá is considered the most important and reliable. My singular focus on Ifá in this paper is rooted in a larger, comparative study of the Ifá divining accoutrements and batá organology; however, much of the comparative approach in this paper is also applicable to the other major divination systems used by orisha devotees. Nonetheless, it should be stated that Ifá can connote a tri-partite scheme signifying: (1) the divination system; (2) the orisha Oruinmila who governs this system; and (3) the religion itself, though this latter usage is not as widely used in Cuba as it is in Nigeria.

11 See William Bascom, "Ifá: Communication between God and Men in West Africa" (Ph.D. diss., University of California at Los Angeles, 1969), 11; M. W. Payne, "Akiwowo, Orature and Divination: Approaches to the Construction of an Emic Sociological Paradigm of Society," Sociological Analysis 53, no. 2 (1992): 184; Welch, "Aspects of Vocal Performance in Shango Praise-Poetry and Song," 19.

12On the term "orature," see M. W. Payne, "Akiwowo, Orature and Divination," 177-78. A serviceable rough approximation is "traditional oral literature."

13 Ibid., 184.

14 Wande Abimbola, Ifá Divination Poetry (New York: NOK Publishers, 1977), 14.

15 See William Bascom, "Ifá: Communication between God and Men in West Africa;" Natalia Bolívar Aróstegui, Los Orichas en Cuba (Ciudad de La Habana: Ediciones Unión, Unión de Escritores y Artistas de Cuba, 1994 [orig. ed., 1954]); Lydia Cabrera, El Monte (Ciudad de La Habana: Editorial Letras Cubanas, 1993); Migene González-Wippler, Introduction to Seashell Divination (New York: Original Publications, 1992).

16Philip Peek, "Introduction: The Study of Divination, Present and Past," in African Divination Systems: Ways of Knowing, ed. Philip M. Peek (Bloomington: Indiana University Press, 1991), 2.

17 Ibid., 2. 
Steven Cornelius describes the effective musical possession rituals of orisha devotees as a "convergence of power," 18 when all well-performed ritual actions coalesce into a point of conjuncture in the ritual motion. An orisha takes possession of one of the devotees present as though a switch has been thrown, a spiritual current entering into an already charged ritual space. As is the case with Ifá divination, the devotees present at these moments become privy to an awareness denied them by quotidian human limitations. Ifá and the batá drumming ritual both effect the moment when devotees can get there from here. And, like Ifá divination, batá drumming also has its contrivances, orature, and sacred accoutrements that must be properly ordered to effect "proper social ordering." 19 Ifá and batá drumming are both divination systems, solidifying a non-normal mode of cognition for the purposes of receiving a non-normal mode of communication. ${ }^{20}$ For some time, there has been a reluctance on the part of Western social sciences to validate mediumistic types of divination due to a Western prejudice against non-normal sensory activity, ${ }^{21}$ but these "intensifying activities facilitate communication between worlds by permitting direct participation of suprahuman entities in this world through ... possession." 22

Traditionally based insights into the nature of the cosmos-and human existence within it-will always be in conflict on some level with the data and/or postulates of empirical thought. A traditional belief system, nonetheless, does propel human action and perception to an extent that it can very well animate any or all of its "irrational" tenets so often refuted by empiricism-for example, the belief in the resurrection of Christ. From these irrational assertions come not only some of the most highly motivated forms of human operation but also the very intellectual processes by which these same human operations might be discredited. Even the empiricist is positioned within, and emerges from, the very cosmological tenets that he or she may choose to vehemently denounce as preposterous. ${ }^{23}$ The same is no less true of the Lukumí religion which has a few of its own highly motivated forms of human operation. Though some may look upon divine contact through human agency as "irrational" action, the similarities between these two modes of effecting divine contact deserve a closer look.

Rosalind Shaw claims that "[w]e tend to allow definitions of 'what is true' in terms of verification to eclipse questions of 'what true means' in other situations." ${ }^{24}$ Shaw goes on to illustrate the point further with an incisive look

\footnotetext{
18Steven Cornelius, "The Convergence of Power: An Investigation into the Music Liturgy of Santería in New York City" (Ph.D. diss., University of California at Los Angeles, 1989).

19Peek, "Introduction: The Study of Divination, Present and Past," 2.

20 Ibid., 4.

21 Ibid., 199.

22 Victor Turner, The Drums of Affliction (Oxford: Clarendon Press, 1972), 4.

23 Amadon-Hampaté Ba, in Welch, "Aspects of Vocal Performance in Shango Praise-Poetry and Song," $\mathbf{x i}$.

24Rosalind Shaw, "Splitting Truths from Darkness: Epistemological Aspects of Temne Divination," in African Divination Systems: Ways of Knowing, ed. Philip M. Peek (Bloomington: Indiana University Press, 1991), 139.
} 
at the "truth" of a courtroom scenario, a truth-authorizing voice in the Western world. The context of "swearing to tell the whole truth" has been endowed with such power that society is willing to make the leap equating appearance with reality. One could say then that the context authorizes illogicity in its need for truth, just as in Lukumí divination.

The question is, "Why the illogical step?" Philip Peek asks this very question with regard to Ifá divination:

The myriad techniques, and uses of divination in African cultures defy any easy categorizations.... Divination systems temporarily shift decision making into a liminal realm by emphatically participating in opposing cognitive modes; in fact, this may be the defining feature of divination. For example, no one could deny that the Ifá divination system of the Yoruba is based on an ancient epistemology or that the Odu verses it generates form a literary book of knowledge; yet the actual process of divination clearly operates in a contrary ("non-rational") mode. Why cast palm nuts to determine which verses to cite? Why not go directly to the verses themselves? ${ }^{25}$

Can an irrational process beget rational results? It seems that divination may indeed be this very juxtaposition. Payne argues for this very hypothesis in his exegesis of Akiwowo's "Orunmilaist Theory of Sociation." ${ }^{26} \mathrm{He}$ states:

Divination can be defined as the process of peering into and disclosing the past, present or future through nonlogical actions. This piercing vision cuts across both material and the spiritual worlds. ${ }^{27}$

Payne uses the ideas of the Italian sociologist, Vilfredo Pareto, as a point of departure for his usage of the term "nonlogical." Nonlogical actions do not link means with ends from the perspective of either the actor or any other person who has more knowledge. Payne, however, goes on to adopt this term to represent "those goals which are approached by means that the current state of Western science is incapable of assessing." 28 In other words, according to Payne's handling of Pareto's idea, since Western science cannot provide any sort of rationale-resonant with its own internal, deductive rules-for the chance casting of objects, Ifá becomes an irrational process to arriving at the orature (which is, incidentally, given considerable value by Western science as a documented epistemology). Ifá divining is therefore, according to Payne, one of these nonlogical actions. The question is whether this framework is applicable not only to causal/interpretive modes of divination, such as Ifá, but also mediumistic modes of divination such as the one effected by the batá drumming rituals of the Lukumí. ${ }^{29}$

25Peek, "African Divination Systems: Non-normal Modes of Cognition," in African Divination Systems: Ways of Knowing, ed. Philip M. Peek (Bloomington: Indiana University Press, 1991), 193.

26Payne, "Akiwowo, Orature and Divination," 179.

27 Ibid., 177.

28 Ibid., 179.

29For some varying looks at typologies of divining modes see J. R. Crawford, Witchcraft and Sorcery in Rhodesia (London: Oxford University Press, 1967); René Devisch, "Perspectives on Divination 
In reference to this issue I will briefly discuss the tratado (treatise), the essential musical form used to organize musical choices, based on previously successful trance-inducing patterns. As a general rule, the tratado provides an opportunity for the musicians to interpret, interact with, or manipulate formal musical structures and lyrical texts to create a synergetic conjuncture whereby all "texts" and ritual intent intersect, affecting the conscious state of one of the participants. Characteristic of the tratado is a selection of songs and drumming which:

(1) facilitate a gradual change in tempo from a slower beginning to a faster ending in the accompanying musical rhythms (toques);

(2) facilitate a gradual change from less intricate to more intricate drumming cells over the course of the tratado;

(3) allow the drummers sufficient repetition of the accompanying toques such that they may make use of conversaciones, floreos (variations), and improvisations in the drumming to heighten the aural experience and, at times, undermine the regularity of the drumming cell much in the same way that the kasélcassé is used in Vodou drumming; ${ }^{30}$

(4) cause a gradual increase in volume (energy/spirited output), both in the drumming and vocal call and response;

(5) allow for the elaboration upon the song text by the lead singer through melismas, intervallic augmentation, the interjection of short epithets and the ayugba (praises to the honoured orisha); ${ }^{31}$

(6) facilitate the common change from strophic texts (usually accompanied by cyclically longer and/or less intricate toques), known as orin, to texts of shorter phrases exchanged between the lead singer and the chorus (usually accompanied by cyclically shorter and/or more intricate toques), known as ègbè.

The tratado, however, should not be seen as simply a formula for possession induction but rather, a socially recognized device augmenting many ritual activities leading to possession. The tratado is an indispensable musical element of possession in the Lukumí religion, but it is not the entire process that induces possession, which does occur outside the musical context. There are, in fact, a great number of musical/sonic elements that follow the tratado

in Contemporary Sub-Saharan Africa," in Theoretical Explorations in African Religions, ed. W. van Binsbergen and M. Schoffeleers (London: KPI/Routledge and Kegan Paul, 1985); William A. Lessa and Evon Z. Vogt, "Introduction to Chapter 7," in Reader in Comparative Religion: An Anthropological Approach (New York: Harper \& Row, 1979); Dominique Zahan, The Religion, Spirituality and Thought of Traditional Africa (Chicago: University of Chicago Press, 1979); and Evan M. Zuesse, Ritual Cosmos: The Sanctification of Life in African Religions (Athens, Ohio: Ohio University Press, 1979).

30Lois Wilckens, The Drums of Vodou (Tempe, Ariz.: White Cliff Media Company, 1992), 48.

31 Given the existence of a drum lexicon, variations in the drumming patterns can also be understood as examples of semantic broadening which provide additional significance to the praises already being intoned by the basic drumming accompaniment, or, they can be understood as interjected praises used to break the repetition of the praise inherent in the toque. This is largely dependent upon which drum head is being varied in the pattern since not all of the drum heads "speak." 
once possession is viewed as imminent. Some of these musical features include:

(1) extended praises (ayugba) - generally non-strophic and irregularly metred-of the lead singer or, if necessary, the use of insults to coax the orisha into taking hold of a devotee;

(2) an even more increased use of drumming calls and responses, variations (floreos), and improvisations by the drummers to accompany the singer's praises;

(3) reduced choral response (if any at all) due to the dialogous nature of the ayugba or non-strophic praise-texts used in conversation with the possessing orisha;

(4) formation of the rueda or "wheel" of dancers that surrounds the individual being possessed;

(5) participatory clapping;

(6) use of a traditional "calling" instrument of the possessing orisha, such as the ashere (maraca) or the agogó (bell);

(7) the shouting of praises welcoming the possessing orisha.

Neither of these lists is meant to be comprehensive. The lists are meant rather to serve as aids to understanding the role of the tratado in the ritual. The tratado is neither stagnant nor inflexible, but, rather, a social construct used to guide the musical choices of the performers as they pertain to musical form and ritual development. The tratado, in a sense, sets out the parameters by which the musicians may (or may not) interpret the musical texts, thus, at the same time, recognising: (1) that the performance of these texts is indeed flexible within prescribed parameters; and (2) that those charged with their interpretation have, to a certain degree, the freedom to render them in a personal manner. ${ }^{32}$ The essence of the tratado, above all, is not meant to dictate musical choice, but rather to effect ritual activity such that a conjuncture of possession or "point of convergence" is likely to occur. The question of means in effecting possession is answered qualitatively as well as quantitatively.

What, then, exists in the Lukumí musical rituals is a highly elaborate and cultivated social stratagem whereby communion with the divine is actuatedas is the case with any form of divination. However, unlike the chance-casting that leads to this communion in Ifá divination, the tratado is not an illogical, or "nonlogical," social action. In fact, the tratado could quite easily be assessed as logically effective in the current state of Western science given its grounding in the study of sensory input and stimulus response. Even without having any particular expertise in these areas of the behavioural sciences, it is not difficult to see how the musical structures are patterned to effect the ecstatic state-a process that parallels many of the socio-musical structures of other ecstatic cults throughout the world. In other words, with regard to Lukumí musical rituals, the means by which non-normal communication is effected is a logical

32Welch, "Aspects of Vocal Performance in Shango Praise-Poetry and Song," 157. 
action contrary to the means of Ifá divination. What is nonlogical in the batá drumming rites is the goal. The current state of Western science is incapable of assessing the outcome or purpose of this logical action. The process whereby musical choices and subsequent socially dictated responses affect the emotional, psychological, and physiological state of a person or persons is, of course, within its common disciplinary realms; however, the nonlogical aspect is that this final state is divine in nature. Batá drumming can, then, be said to seek out nonlogical outcomes, those goals which are attained, though understood to be impossible-in this case, divine contact, or perhaps, divining contact.

Ifá divination exhibits nonlogical action-irrational means to a rational end-whereas batá drumming inverts this association, making use of a rational means to an irrational end-ordering social action so that a person may enter into an altered state of consciousness, providing the larger community with divine contact. If, in the end, we return to Peek's thesis that divination is that process which creates a non-normal mode of cognition to receive non-normal communication, ${ }^{33}$ then the diviner is the individual whose expertise effects the contact between the two worlds. In this light, the drummer is a diviner. ${ }^{34}$

Among a multitude of symbolic, material, and ritual similarities between Ifá divination and batá drumming, what links them together in such a compelling manner is the importance of performed texts-orature-and the power of words in the "logical/nonlogical" interplay. While the effectiveness of Ifá divination is based on the nonlogical, chance-casting of sacred objects such that the orisha indicate to the diviner the relevant texts for the client's wellbeing, batá drumming uses texts embedded in the efficacious sonorities of Lukumí music-making to bring about contact with the divine. What exists is a unity of purpose through inverted social action-each employing logical and nonlogical activity, though at different moments in their respective rituals.

There has been little scholarly attention paid to possession as a divining mode-perhaps the inevitable result of a mainstream Western scholarly mindset inimical to the validation of non-normal sensory activities. ${ }^{35}$ If, in the final analysis, it is the nonlogical outcome-divine contact-that is the essential aspiration of this musical behaviour and sacred expression, then, the musical behaviour is a divining mode. Through orature performance, these two traditions render effective important social action and simultaneously articulate the intellectual and spiritual tradition of the community of devotees. ${ }^{36}$ As Ba states, "Our traditions ... are the very basis for our intellectuality." ${ }^{77}$ It

33Peek, "Introduction: The Study of Divination, Present and Past," 4.

34 If there is a distinction to be made between the diviner as the manipulator/reader of accoutrements (interpretive mode) and one as communicator (oracular mode), then both the drummer and the possessed devotee (eshin orisha) are a collective diviner. Perhaps this idea might be useful in the future creation of a more comprehensive typology of divining modes, being a possible sub-genre of mediumistic divining whereby the divining is shared or communal in nature.

35Peek, "African Divination Systems: Non-Normal Modes of Cognition," 199.

36Payne, "Akiwowo, Orature and Divination," 184.

37 Amadon-Hampaté Ba, in Welch, "Aspects of Vocal Performance in Shango Praise-Poetry and Song," $x i$. 
follows, then, that the musical tradition be understood not as a mirror of what is important socially, but, instead, as a mode through which what is socially important exists.

\begin{abstract}
This paper is an examination of similarities between batá drumming and Ifá divination among the Afrocuban socio-religious group, Lukumí. Primarily addressing the use of diametrically opposed social actions within each of these practices, the paper maintains that this juxtaposition of opposites is a constituent characteristic of divining modes-be they interpretive or mediumistic-in effecting suprahuman communication. The paper purports the necessity to examine batá drumming as a divination system; thus, it argues the need for an expanded construct of divination that can readily include musical behaviours such as possession induction.
\end{abstract}

